\title{
PENILAIAN IMPLEMENTASI KURIKULUM 2013 PADA MATA PELAJARAN PENJASKES TINGKAT SEKOLAH DASAR NEGERI 4 MEMPAWAH HILIR
}

\author{
Tri Liana \\ Sekolah Dasar Negeri 4 Mempawah Hilir \\ Email: Triliana@gmail.com
}

\begin{abstract}
This study aims to find out:1) Curriculum 2013 implementation, 2) describe the constraints faced in the implementation of the curriculum 2013,3) the strategy used in the implementation 2013 curriculum in the orchestra education in public elementary school 4 Mempawah. This study is an evaluation research using the CIPP (Contex, Input, Process and Product) developed by Stufflebeam. Data was obtained through curriculum expert validation questionnaires, observation and interviews. Data analysis was carried out qualitative. The results of the study show that: 1) the implementation of the Curriculum 2013 has largely gone smoothly, from 4 schools incorporated only 1 school has not fully planned the implementation of Curriculum 2013, due to the lack of socialization and assistance to teacher and the lack of available facilities at school, 2) the obstacles faced in the implementation of the Curriculum 2013 were the lamitations of orchestra teacher and the limited of infrastructure to support practical activities and the lack of supporting books, library and internet network. 3) the strategy to overcome the obctacles in the implementation of curriculum 2013 that needs to be prepared furthur is to make good planning based on needs analysis and the existence of good synergies between the central goverment and the provincial as well as local government. There are still many confusions, this is due to the large number of assesment components that must be carried out as demands of the Curriculum 2013.
\end{abstract}

\section{Keywords: Assesment Implementation of the Curriculum 2013, Physical Education}

\section{PENDAHULUAN}

Pemerintah terus berupaya untuk meningkatkan mutu pendidikan nasional, salah satunya dengan melakukan penyempurnaan kurikulum. Saat ini, dunia pendidikan Indonesia ramai diperbincangkan mengenai penerapan kurikulum 2013. Penilaian tersebut dilaksanakan oleh Dinas Pendidikan dan Kebudayaan yang bertujuan mengetahui hal yang berkaitan dengan Kurikulum tersebut. Kegiatan penilaian dilakukan secara rutin untuk mengetahui apakah ada kesulitan dalam implementasi Kurikulum 2013 di sekolah yang kemudian dari kesulitan-kesulitan yang ada bisa mencarikan solusi supaya masalah yang dihadapi kepala sekolah dan guru bisa terselesaikan. Kurikulum 2013 merupakan kurikulum terbaru yang menitik beratkan penggunaan pendekatan safik, penilaian autentik dan tematik integratif dalam pembelajarannya. Kurikulum ini diharapkan mampu mencetak generasi Indonesia yang kritis dan kreatif sesuai dengan tuntutan perkembangan zaman. Faktor pendukung penilaian implementasi Kurikulum 2013 meliputi buku pedoman yang diberikan ketika sosialisasi Kurikulum 2013, arahan dari pengawas, fasilitas sekolah, dan sosialisasi dari pihak terkait. Dengan adanya faktor pendukung tersebut guru-guru memanfaatkan dengan cara menggunakan buku pedoman untuk menyusun berbagai administrasi kurikulum, memanfaatkan 
fasilitas sekolah semaksimal mungkin untuk menunjang pembelajaran, dan mencari solusi dari setiap masalah yang dihadapi bersama dengan kepala sekolah. Apabila kepala sekolah dan guru tidak menemukan solusi dari masalah yang ada, maka kepala sekolah meminta bantuan kepada pengawas sekolah untuk mencari solusi dari masalah tersebut.

Penilaian yang dilakukan guru untuk mengisi rapor dilihat dari penilaian portofolio, rubrik penilaian, penilaian diri sendiri, dan juga dilihat dari ulangan harian atau tugas yang telah diberikan oleh guru. SKL Kurikulum 2013 berisi mengenai sikap, pengetahuan, dan keterampilan siswa. Implementasi Kurikulum 2013 tidak ada siswa yang tidak naik kelas karena siswa memiliki kelebihan tersendiri pada setiap kompetensi dasar, sehingga meskipun hanya menguasai satu kompetensi dasar mereka tetap bisa dinyatakan naik kelas.

Orang tua siswa dan siswa juga merupakan salah satu pendukung dalam implementasi Kurikulum 2013. Orang tua siswa memberikan dukungan dengan membantu dan mengawasi siswa belajar di rumah serta orang tua mendukung adanya Kurikulum 2013 karena hal itu bisa memudahkan anak dalam belajar. Hambatan yang dihadapi oleh pihak sekolah terutama guru dalam implementasi Kurikulum 2013 yaitu masih terlalu banyak administrasi yang harus diselesaikan, pembuatan RPP harus mencantumkan tiga pendekatan, satu RPP digunakan untuk satu kali pertemuan, guru merasa kesulitan dalam membagi waktu antara pelaksanaan pembelajaran dan administrasi, serta guru kesulitan dalam melakukan penilaian karena penilaian yang cukup banyak. SD NEGERI 4 kecamatan Mempawah Hilir Kabupaten Mempawah dalam mengatasi masalah terkait materi yang belum selesai yakni dengan guru memberikan tugas mandiri terkait dengan materi yang belum tuntas dan memberikan tambahan materi pada hari selanjutnya sebelum masuk pokok bahasan baru serta guru meminta bantuan kepada orang tua siswa untuk membantu siswa memahami secara detail tema yang belum selesai.
Otoritas pengawas sekolah, kepala sekolah, dan guru. Masing-masing otorisator juga memiliki cara sendiri dalam menangani masalah yaitu dengan memberikan motivasi, memonitoring, dan juga menyediakan dana untuk keperluan implementasi Kurikulum 2013. Memanfaatkan waktu sebaik mungkin supaya pembelajaran bisa berjalan optimal dan sharing dengan guru-guru dan kepala sekolah apabila ada kesulitan dalam implementasi Kurikulum 2013.

Kepala sekolah memiliki penting dalam implementasi Kurikulum 2013. Kepala sekolah dalam implementasi Kurikulum 2013 memiliki peran yaitu memberikan dukungan dan motivasi, memonitoring dan menyampaikan ilmu yang diperoleh ketika mengikuti sosialisasi kepada guru-guru, selain itu kepala sekolah melakukan supervisi kelompok, yaitu dengan kepala sekolah mengadakan rapat untuk membahas kesulitan guru dalam proses pembelajaran baik untuk implementasi Kurikulum 2013 maupun KTSP.

Kepala sekolah juga memberikan kesempatan kepada guru untuk meningkatkan profesinya dan mendorong guru dalam mengikuti kegiatan yang bisa menunjang implementasi Kurikulum 2013. Guru juga memiliki peran dalam implementasi Kurikulum 2013. Guru yang dimaksud disini yaitu guru yang melaksanakan Kurikulum 2013 dan guru yang belum melaksanakan Kurikulum 2013. Peran guru pelaksana dalam implementasi Kurikulum 2013 yaitu memberikan dukungan dan juga motivasi antar sesama guru pelaksana dan membagikan ilmu yang diperoleh ketika mengikuti sosialisasi kepada guru-guru yang tidak mengikuti sosialisasi. Sedangkan peran guru bukan pelaksana dalam implementasi Kurikulum 2013 yaitu memberikan motivasi dan dukungan kepada guru yang melaksanakan Kurikulum 2013.

Penilaian implementasi Kurikulum 2013 dilaksanakan ditingkat SD. Kurikulum 2013 dilaksanakan untuk membentuk karakter dan keterampilan dari masing-masing siswa. Pemerintah memberikan sosialisasi selama implementasi Kurikulum 2013 berupa diklat 
untuk menunjang kelancaran implementasi Kurikulum 2013 dan supaya guru memperoleh wawasan mengenai Kurikulum 2013. Mulyasa (2013:48) mengungkapkan sosialisasi dalam implementasi kurikulum sangat penting dilakukan, agar semua pihak yang terlibat dalam implementasinya di lapangan paham dengan perubahan yang harus dilakukan sesuai dengan tugas pokok dan fungsinya masing-masing, sehingga mereka memberikan dukungan terhadap perubahan kurikulum yang dilakukan. SD NEGERI 4 kecamatan Mempawah Hilir Kabupaten Mempawah dalam implementasi Kurikulum 2013 juga melakukan sosialisasi terhadap guru-guru dan orang tua siswa, selain itu guru-guru dan kepala sekolah juga mengikuti diklat yang diadakan oleh pemerintah untuk kesuksesan implementasi Kurikulum 2013.

Alternatif pemecahan masalah dalam implementasi Kurikulum 2013 yang sudah dilakukan di SD NEGERI 4 kecamatan Mempawah Hilir Kabupaten Mempawah terkait dengan pembelajaran yang belum tuntas yakni guru memberikan tugas tambahan, guru juga memberikan tambahan pada hari berikutnya sebelum jam pelajaran dimulai, dan guru meminta bantuan kepada wali murid untuk mengawasi dan membimbing anaknya dalam belajar di rumah supaya anak bisa lebih memahami materi yang belum tuntas dan jika ada yang belum di mengerti, siswa bisa menanyakan materi yang belum dimengerti kepada guru.

Kendala yang dihadapi selain masalah pembelajaran yaitu untuk siswa harus telaten dan sabar dalam mengajari. Peranan kepala sekolah, guru pelaksana, dan guru bukan pelaksana bisa dikatakan opimal karena kepala sekolah sudah melaksanakan perannya dengan baik yaitu dengan memonitoring, membantu guru dalam memecahkan masalah, dan menyediakan bantuan berupa materiil dan non materiil serta SD NEGERI 4 kecamatan Mempawah Hilir Kabupaten Mempawah sudah mendapatkan monitoring langsung dari dinas pendidikan dan kebudayaan setempat terkait implementasi Kurikulum 2013 baik kepada kepala sekolah dan juga proses belajar mengajar yang dilakukan oleh guru pelaksana. Penelitian penilaian implementasi Kurikulum 2013 banyak dilakukan di sekolah-sekolah menemukan ada kendala guru sekolah dasar dalam mengimplementasikan Kurikulum 2013 yang berasal dari pemerintah, institusi, guru, orang tua siswa dan guru. Hapsari (2015) dalam penelitiannya menemukan bahwa kemampuan guru dalam mengembangkan, mengimplementasikan, dan mengpenilaian Kurikulum 2013 cukup baik. Demikian pula hasil penilaian pendampingan yang dilakukan oleh Puslitbang Kemdikbud di sekolah piloting menunjukkan bahwa pemahaman guru terhadap buku, RPP, proses pembelajaran, dan penilaian sangat baik.

Uraian di atas menunjukkan perlunya penelitian penilaian implementasi Kurikulum 2013 terutama pada sekolah pelaksana mandiri. Penelitian ini bertujuan untuk mendapatkan informasi tentang kesiapan, pelaksanaan, dan hasil implementasi kurikulum. Kesiapan implementasi meliputi kesiapan buku, guru, sarana prasarana, dan kondisi RPP. Pelaksanaan implementasi meliputi proses dan penilaian pembelajaran. Hasil implementasi meliputi respon siswa dan perolehan hasil belajar.

\section{METODE PENELITIAN \\ Pendekatan dan Jenis Penelitian}

Dalam penelitian ini peneliti mengambil Pendekatan yang berorientasi sebagai Pemakai (Consumer-oriented), (Muzayanah, 2012:131), karena dianggap cocok dengan jenis penelitian penilaian program terhadap Pelaksanaan atau impelementasi Kurikulum 2013 pada Mata Pelajaran Penjas di SD Negeri 4 kecamatan Mempawah Hilir Kabupaten Mempawah. Penelitian ini tergolong penelitian deskriptif yaitu hanya terbatas pada usaha mengungkapkan suatu masalah dan keadaan sebagaimana adanya, sehingga hanya sekedar mengungkapkan fakta. Jenis penilaian dalam penelitian ini adalah penilaian kurikulum. Penilaian kurikulum dilakukan terhadap Pelaksanaan Kurikulum 2013 pada Mata Pelajaran Penjas 
di SD Negeri 4 kecamatan Mempawah Hilir Kabupaten Mempawah.

\section{Metode Penelitian}

Penelitian penilaian ini dilakukan di SD

Negeri 4 kecamatan Mempawah Hilir Kabupaten Mempawah yang merupakan sekolah pelaksana mandiri. Model penilaian yang digunakan adalah model CIPP. Model penilaian CIPP ini merupakan sebuah singkatan dari huruf awal, yaitu: Context evaluation, Input evaluation, Process evaluation, dan Product evaluation.

Metode penelitian merupakan langkah dan cara dalam mencari, merumuskan, menggali data, menganalisis, membahas dan menyimpulkan masalah dalam penelitian, metode dalam pengertian ini lebih bersifat praktis dan aplikatif, bukan sebuah cara yang bersifat teoritis-normatif sebagaimana dalam konsep metodologi. ( Musfiqon,2012: 14). Data hasil wawancara dianalisis menggunakan metode deskripstif kualitatif, sedangkan data hasil observasi dianalisis menggunakan metode deskriptif kuantitatif dengan kriteria yang telah ditentukan.

\section{Desain Penelitian}

Desain penilaian dalam penelitian ini merupakan rincian dan langkah apa yang diperlukan untuk menjawab tiap pertanyaan penilaian. Desain penilaian mencakup rencana proses maupun produk secara tertulis, desain yang dipilih nantinya mempunyai implikasi terhadap sumber dan metode pengumpulan data. Model penilaian yang digunakan dalam desain penelitian ini adalah CIPP Evaluation Model. Model ini dikembangkan oleh Stafflebeam dkk menekankan empat hal pokok yaitu Penilaian konteks untuk membantu keputusan perencanaan; menentukan kebutuhan apa yang diperlukan dalam program pendidikan.

\section{Sumber Data}

Sumber data dalam penelitian ini adalah pihak-pihak yang terkait dengan implementasi Kurikulum 2013, seperti Kepala Sekolah, Guru, pengawas, Komite/orang tua siswa dan siswa.

\section{Lokasi Penelitian}

Penelitian ini dilakukan di SD Negeri 4 kecamatan Mempawah Hilir Kabupaten
Mempawah pada mata pelajaran Penjas tahun pelajaran 2017/2018, dan direncanakan mulai bulan April 2018 sampai dengan bulan Juni 2018.

\section{Teknik Pengumpulan Data}

Teknik pengumpulan data pada penelitian ini akan menuturkan dan menafsirkan data yang berkaitan dengan situasi yang terjadi, sikap, fenomenafenomena dan pandangan tentang proses dan hasil implementasi Kurikulum 2013 di SD Negeri 4 kecamatan Mempawah Hilir Kabupaten Mempawah.

Untuk memperoleh data dalam penelitian ini, peneliti melakukan dengan teknik observasi langsung, teknik komunikasi langsung dan studi dokumenter. Dengan menggunakan instrumen kepada pihak-pihak yang terkait dengan impelementasi Kurikulum 2013 yaitu Kepala Sekolah, Wakil Kepala Sekolah Bidang Kurikulum, Guru, siswa orang tua siswa, komite dan pengawas sekolah.

\section{Instrumen Penelitian}

Dalam penelitian ini, peneliti sebagai instrumen utama dan menggunakan pedoman observasi, pedoman wawancara, dan dokumentasi sebagai alat bantu untuk memperoleh data dilapangan.

\section{Observasi}

Dalam penelitian ini peneliti menggunakan teknik observasi nonpartisipan, dimana peneliti tidak terlibat langsung dengan aktivitas orang-orang yang sedang diamati. Yang diamati dalam observasi ini adalah Implementasi pembelajaran penjas orkes dari persiapan, pelaksanaan, sampai penilaian pembelajaran. Untuk pengamatan menggunakan pedoman observasi yang diambil dari kemendikbud, untuk pedoman observasi persiapan dan pedoman observasi pelaksanaan pembelajaran, sedangkan pedoman observasi penilaian pembelajaran diambil dari monitor tugas yang diberikan oleh guru.

\section{Wawancara}

Sugiyono (2011:317) menjelaskan bahwa, "wawancara digunakan sebagai teknik pengumpulan data apabila peneliti ingin melakukan studi pendahuluan untuk 
menemukan permasalahan yang harus diteliti, tetapi juga apabila peneliti ingin mengetahui hal-hal dari responden yang lebih mendalam". Dalam penelitian kualitatif, sering menggabungkan teknik observasi partisipatif dengan wawancara mendalam. Selama melakukan observasi, peneliti juga melakukan wawancara dengan orang-orang yang ada di dalamnya. Pengambilan data dengan menggunakan teknik wawancara, dilakukan peneliti setelah selesai melakukan observasi pembelajaran Penjas. Hal ini dilakukan agar hasil yang didapatkan oleh peneliti saat observasi dapat dipertegas lagi dari pernyataan tiga narasumber, yaitu guru Penjas, Kepala Sekolah, dan siswa SD Negeri 4 kecamatan Mempawah Hilir Kabupaten Mempawah.

Teknik wawancara yang digunakan dalam penelitian ini adalah wawancara semi terstruktur agar subjek penelitian lebih terbuka dalam memberikan data. Dalam penelitian ini, wawancara digunakan untuk memperoleh data tentang implementasi pembelajaran Penjas berdasarkan kurikulum 2013 di SD Negeri 4 kecamatan Mempawah Hilir Kabupaten Mempawah. Wawancara dilakukan dengan guru Penjas, Kepala Sekolah dan beberapa siswa kelas atas yang diambil dari siswa kelas IV SD Negeri 4 kecamatan Mempawah Hilir Kabupaten Mempawah. Berikut ini adalah pedoman wawancara yang digunakan oleh peneliti untuk memperoleh data penelitian.

\section{Dokumentasi}

Sebagaimana dikemukakan oleh Ridwan (2014: 105) bahwa studi dokumentasi adalah,"untuk memperoleh data langsung dari tempat penelitian, meliputi buku=buku yang relevan, peraturanperaturan, laporan kegiatan,foto-foto, film dokumenter, data yang relevan penelitian".

Dokumentasi dalam penelitian ini untuk mengetahui implementasi pembelajaran Penjas kelas IV berdasarkan kurikulum 2013 melalui RPP, daftar nilai mingguan, daftar nilai UTS, daftar nilai UAS, daftar penilaian, perbaikan, dan pengayaan, hasil observasi, dan foto. Dalam penelitian ini, peneliti terjun langsung ke lapangan dalam proses observasi, wawancara, dan dokumentasi.

\section{Validasi Instrumen}

Instrumen yang dipergunakan dalam pengumpulan data dalam penelitian ini terlebih dahulu divalidasi ahli atau pakar dalam bidang kurikulum 2013, dalam hal ini yang bertindak sebagai validator adalah bapak Prof.Dr.Aunurrahman,M.Pd

\section{Validasi Data}

Untuk menguji validitas data dilakukan beberapa teknik dan prosedur kepercayaan data, menurut Sugiyono.(2009:121) bahwa," uji keabsahan data dalam penelitian kualitatif meliputi uji Credibility (validitas internal), transferability (validitas eksterna), defenability (reliabilitas), dan confirmability (obyektivitas). Uji kredibilitas data atau kepercayaan terhadap data hasil penelitian kualitatif antara lain juga dapat dilakukan dengan perpanjangan pengamatan, peningkatan ketekunan dalam penelitian, triangulasi, diskusi dengan teman sejawat, analisis kasus negatif dan member check. Triangulasi dalam pengujian kredibilitas diartikan sebagai pengecekan data dari berbagai sumber dengan berbagai cara, dan berbagai waktu. Triangulasi sumber untuk menguji kredibilitas data dilakukan dengan cara mengecek data yang telah diperoleh melalui beberapa sumber. Triangulasi teknik untuk menguji kredibilitas data dilakukan dengan cara mengecek data kepada sumber yang sama dengan teknik yang berbeda. Triangulasi waktu untuk menguji kredibilitas data dilakukan dengan cara pengecekan dengan wawancara, observasi atau teknik lain dalam waktu atau situasi yang berbeda, bila hasil uji menghasilkan data yang berbeda, maka dilakukan secara berulangulang sehingga sampai ditemukan kepastian datanya.

Triangulasi dilakukan dengan langkahlangkah sebagai berikut: 1) Pengecekan hasil wawancara dengan siswa, dengan guru dan dengan kepala sekolah. 2) Soal tes pemahaman materi terlebih dahulu di uji cobakan pada kelas yang telah mempelajari materi pelajaran Penjas pada sekolah yang berbeda, yaitu pada kelas IV. Faktor lain 
yang diperhatikan adalah melihat latar belakang kemampuan siswa dari sisi materi, kualitas siswa, kemampuan siswa dalam menjawab butir soal dan hasilnya didiskusikan kembali dengan guru dan kepala sekolah.

Dalam hal ini peneliti untuk uji kredibilitas lebih banyak melakukan diskusi atas temuan dengan teman sejawat. 1) Transferability (Kemampuan Transfer) yaitu: dalam teknik ini diperoleh jawaban atas pengalaman yang tidak dapat dijawab oleh peneliti melalui deskripsi prosedur, konteks, kegiatan dan langkah-langkah yang jelas memungkinkan penemuan atau hasil penelitian ini dapat diterapkan atau diaplikasikan oleh orang lain, ditempat yang berbeda yang memiliki persoalan yang serupa. 2) Depenability (pertanggung jawaban) yaitu Teknik ini merupakan proses pengumpulan data dan interpretasi temuan dan melaporkan hasil penelitian, semakin konsisten seorang peneliti dalam keseluruhan proses penelitiannya, maka akan semakin memenuhi standar dependabilitas.

\section{Teknik Analisis Data}

Analisis data merupakan proses untuk mencari dan menyusun secara sistemmatis data yang diperoleh dari hasil suatu wawancara, kuesioner, maupun catatan di lapangan sehingga dapat dengan mudah dipahami dan di informasikan kepada pihak lain. Analisis data memiliki tiga unsur yakni: (1) Reduksi data; (2) Penyajian data; (3) Penarikan kesimpulan dan verifikasi.

\section{HASIL PENELITIAN DAN PEMBAHASAN \\ Hasil Penelitian}

Indikator dalam evaluasi konteks dalam implementasi kurikulum 2013 ini terdiri dari: 1) Sarana dan Prasarana yang tersedia. 2) Pemahaman Guru terhadap kurikulum 2013. 3) Pemahaman siswa terhadap kurikulum 2013. 4) Keterlibatan Komite sekolah atau orang tua siswa dalam implementasi kurikulum 2013.

\section{Sarana dan Prasarana Yang Tersedia}

Data yang diperoleh dari hasil kuesioner terhadap sarana dan prasarana yang ditujukan kepada kepala sekolah, Pengawas, guru olahraga, siswa dan komite sekolah di Sekolah Dasar Negeri 4 Kecamatan Mempawah Hilir Kabupaten Mempawah sebagai berikut:

Tabel 1. Skor Nilai Komponen Sarana dan Prasarana

\begin{tabular}{llrllll}
\hline No & $\begin{array}{l}\text { Respo } \\
\text { nden }\end{array}$ & $\begin{array}{l}\text { Jum } \\
\text { lah }\end{array}$ & n & N & DP & $\begin{array}{l}\text { Kesim- } \\
\text { Pulan }\end{array}$ \\
\hline 1 & $\begin{array}{l}\text { Kepala } \\
\text { Sekolah }\end{array}$ & 4 & 30 & 60 & $50 \%$ & $\begin{array}{l}\text { Kurang } \\
\text { Baik }\end{array}$ \\
\hline 2 & $\begin{array}{l}\text { Pengaw } \\
\text { as }\end{array}$ & 1 & 10 & 15 & $\begin{array}{l}66,67 \\
\%\end{array}$ & Cukup \\
\hline 3 & Guru & 4 & 30 & 60 & $50 \%$ & $\begin{array}{l}\text { Kurang } \\
\text { Baik }\end{array}$ \\
\hline 4 & Siswa & 20 & 180 & 300 & $60 \%$ & Cukup \\
\hline 5 & $\begin{array}{l}\text { Komite } \\
\text { Sekolah }\end{array}$ & 4 & 36 & 60 & $60 \%$ & Cukup \\
\hline & Jumlah & 33 & & & & \\
\hline
\end{tabular}

Keterangan:

$\mathrm{n}=$ Skor Nilai Yang Diperoleh Dari Jawaban Responden

$\mathrm{N}=$ Skor Ideal Seluruh Responden

DP $=$ Deskripsi Persentase

\section{Pemahaman Guru Terhadap Kurikulum} 2013

Sedangkan data yang diperoleh dari hasil wawancara tentang pemahaman guru terhadap kurikulum 2013 pada Sekolah Dasar Negeri 4 Kecamatan Mempawah Hilir Kabupaten Mempawah sebagai berikut: "Belum mengetahui, karena belum pernah mengikuti pelatihan Kurikulum 2013, masih kurang memahmi, karena saya belum pernah mengikuti penataran tentang Kurikulum 2013.

Keterlibatan Komite Sekolah Terhadap Pengembangan Kurikulum

Berikutnya data yang diperoleh dari hasil wawancara kepada orang tua siswa/komite Sekolah terkait keterlibatan komite sekolah dalam pengembangan kurikulum pada Sekolah Dasar Negeri 4 Kecamatan Mempawah Hilir Kabupaten Mempawah sebagai berikut: "Kami belum pernah diberitahukan oleh pihak sekolah jika 
sekarang telah menggunakan kurikulum 2013, belum bisa memberikan pendapat karena belum mengetahuinya, sebaiknya pemerintah gencar untuk mensosialisasikan kurikulum 2013 ini baik langsung terhadap masyarakat ataupun lewat instansi terkait, seperti dinas pendidikan dan kebudayaan, pemda ataupun kepala sekolah.

\section{Pelatihan dan Pendampingan Guru}

Pelatihan dilakukan secara berjenjang sesuai dengan tingkatan sekolah masingmasing dan lokasi sekolah masing-masing. pelatihan ini diselenggarakan oleh Dinas Pendidikan melalui sekolah dan Lembaga Penjamin Mutu Pendidikan. Informasi tentang kegiatan pelatihan dan pendampingan guru diperoleh dari pembagian kuesioner dan pedoman wawancara dengan responden. Kuesioner dibagikan kepada ekepala sekolah, guru dan pengawas. Untuk aspek pelatihan guru, meliputi indikator sebagai berikut: a) Kesesuaian materi pelatihan dengan kebutuhan guru. b) Kesesuaian kompetensi

\begin{tabular}{clllll}
\hline $\begin{array}{c}\text { No Respon } \\
\text { den }\end{array}$ & $\begin{array}{l}\text { Jum } \\
\text { lah }\end{array}$ & n & N & DP & $\begin{array}{l}\text { Kesim } \\
\text { pulan }\end{array}$ \\
\hline
\end{tabular}

\begin{tabular}{lllllll}
\hline 1 & Guru & 4 & 90 & 120 & $75 \%$ & Baik \\
\hline & Jumlah & 4 & - & - & - & \\
& & & & & & \\
\hline
\end{tabular}

instruktur yang memberikan pelatihan dengan materi pelatihan. c) Kesesuaian alokasi waktu yang tersedia dengan materi pelatihan. d) Penyampaian materi. e) Pengembangan Karakter Untuk aspek pendampingan diperoleh data dengan indikator kunjungan dan pendampingan yang dilakukan oleh TIM dari dinas terkait. Berdasarkan hasil analisis data yang diperoleh dari kepala sekolah, guru dan pengawas, dapat dilihat pada tabel berikut ini.

\section{Tabel 2. Tabel Skor Nilai Aspek Pelatihan dan Pendampingan Guru}

Keterangan:

$\mathrm{n}=$ Skor nilai yang diperoleh dari jawaban responden

$\mathrm{N}=$ Skor ideal seluruh responden

DP $=$ Deskripsi Persentase
Berdasarkan data dan hasil yang diperoleh dapat dikatakan bahwa pelaksanaan pelatihan dan pendampingan terhadap kepala sekolah, guru dan pengawas, diperoleh bahwa; persepsi kepala sekolah "pelatihan berjalan dengan cukup baik, yaitu 66,67\% sedang persepsi guru masih kurang baik, yaitu $50 \%$. dan persepsi pengawas $66,67 \%$ juga sudah tergolong Cukup Baik. Sedangkan berdasarkan hasil wawancara yang dilakukan kepada 4 orang guru, diperoleh informasi dan data sebagai berikut: "Saya guru penjaskesorkes baru di sekolah ini dan masih berstatus honorer.

\section{Manajemen pembelajaran}

Manajemen pembelajaran itu cukup penting untuk diperhatikan, karena dari sinilah semuanya di mulai. Sebuah manajemen yang baik akan dapat menentukan baik buruknya suatu proses pembelajaran, kesemuanya ini telah dimulai ketika seorang guru mempersiapkan Rencana proses Pembelajaran.

Tabel 3. Skor Nilai Manajemen Pembelajaran

\begin{tabular}{llccccc}
\hline No & $\begin{array}{l}\text { Respon } \\
\text { den }\end{array}$ & $\begin{array}{c}\text { Jum } \\
\text { lah }\end{array}$ & n & N & DP & $\begin{array}{c}\text { Kesim } \\
\text { pulan }\end{array}$ \\
\hline 1 & $\begin{array}{l}\text { Kepala } \\
\text { Sekolah }\end{array}$ & 4 & 40 & 60 & $\begin{array}{l}66,67 \\
\%\end{array}$ & Cukup \\
\hline 2 & Guru & 4 & 30 & 60 & $50 \%$ & Kurang \\
\hline 3 & Pengawas & 1 & 10 & 15 & $\begin{array}{l}66,67 \\
\%\end{array}$ & Cukup \\
\hline & Jumlah & 9 & & & & \\
\hline
\end{tabular}

Keterangan:

$\mathrm{n}=$ Skor nilai yang diperoleh dari jawaban responden

$\mathrm{N}=$ Skor ideal seluruh responden

DP $=$ Deskripsi Persentase

Berdasarkan indikator yang ditetapkan diperoleh rata-rata persentase sebesar $75 \%$ yang berarti bahwa aspek manajemen pembelajaran di sekolah sudah melaksanakan kurikulum 2013 dengan baik. Berdasarkan data yang diperoleh,,dapat dikatakan bahwa hasil evaluasi menunjukkan bahwa pihak sekolah sudah berusaha dengan baik untuk mengelola atau mengatur segala aktivitas pembelajaran agar sesuai dengan ketentuan yang ada di kurikulum 2013 walaupun masih 
terdapat kekurangan dibeberapa hal seperti buku pedoman pelaksanaan kurikuluj 2013, baik untuk guru maupun untuk siswa serta ketersediaan fasilitas pendukung khususnya dalam pelajaran penjaskes-orkes.

\section{Layanan Kesiswaan}

Informasi yang diperoleh terkait layanan kesiswaan berdasarkan kuesioner yang dibagikan kepada komite atau orang tua siswa yang berjumlah 4 orang, dengan indikator yaitu: 1) Layanan bantuan kesulitan belajar. 2) Layanan konsultasi dengan orang tua dan siswa. 3) Layanan adminstrasi kesiswaan. 4) Layanan peminatan. 5) Layanan bimbingan dan konseling.

Tabel 4. Layanan Kesiswaan

\begin{tabular}{llccccc}
\hline No & Responden & $\begin{array}{l}\text { Jum } \\
\text { lah }\end{array}$ & n & N & DP & $\begin{array}{l}\text { Kesim } \\
\text { pulan }\end{array}$ \\
\hline 1 & $\begin{array}{l}\text { Komite } \\
\text { Sekolah }\end{array}$ & 4 & 18 & 25 & $72 \%$ & Baik \\
\hline & Jumlah & 4 & & & & \\
\hline
\end{tabular}

$\mathrm{n}=$ Skor nilai yang diperoleh dari jawaban responden

$\mathrm{N}=$ Skor ideal seluruh responden

DP $=$ Deskripsi Persentase

Berdasarkan indikator yang ditetapkan diperoleh rata-rata persentase sebesar $75 \%$ yang berarti bahwa aspek manajemen pembelajaran di sekolah sudah melaksanakan kurikulum 2013 dengan baik. Berdasarkan data yang diperoleh,,dapat dikatakan bahwa hasil evaluasi menunjukkan bahwa pihak sekolah sudah berusaha dengan baik untuk mengelola atau mengatur segala aktivitas pembelajaran agar sesuai dengan ketentuan yang ada di kurikulum 2013 walaupun masih terdapat kekurangan dibeberapa hal seperti buku pedoman pelaksanaan kurikuluj 2013, baik untuk guru maupun untuk siswa serta ketersediaan fasilitas pendukung khususnya dalam pelajaran penjaskes-orkes.

Berdasarkan data pada table 4 tersebut di atas diperoleh skor $72 \%$ sehingga dapat disimpulkan bahwa layanan kesiswaan di empat sekolah dasar negeri 4 Kecamatan Mempawah Hilir, Kabupaten Mempawah telah terlaksana dengan baik. Harapan ke depan layanan kesiswaan dapat terus untuk ditingkatkan kualitasnya agar program layanan yang diprogramkan dapat terlaksanakan sebagaimana mestinya. Guru diharapkan dapat memberikan layanan remedial yang maksimal melalui pembelajaran remedial dengan jalan melaksanakan pengajaran terhadap tujuan yang tidak dapat dicapai oleh siswa dan dapat memberikan tambahan waktu bagi siswa yang memerlukan.

Berdasarkan hasil wawancara tersebut di atas dapat dikatakan bahwa guru olahraga di sekolah negeri 4 Kecamatan Mempawah Hilir, Kabupaten Mempawah memilih untuk menyediakan buku secara mandiri, artinya dalam hal ini dibelai sendiri di toko buku yang tersedia. Hal ini terjadi dikarenakan buku yang semestinya disediakan oleh pihak sekolah terjadi kendala dan beberapa hambatan karena pencairan dana bos dan manajemen yang berbelit untuk pengadaannya. Hal inilah yang menyebabkan guru dan murid memutuskan untuk membeli buku dengan cara sendiri di toko buku.

Disamping hal tersebut di atas, dalam pengadaan buku ini juga, guru semuanya membeli buku tetapi untuk siswa, hanya sedikit siswa yang membeli buku tersebut. a) Evaluasi Proses (Process) Dalam Implementasi Kurikulum 2013. Evaluasi proses dalam penelitian ini selalu menekankan pada beberapa tujuan, diantaranya evaluasi proses digunakan untuk menduga apa yang akan terjadi atas rancangan prosedur atau rancangan implementasi dari kurikulum 2013 selama ini.

Evaluasi proses dalam implementasi kurikulum 2013 pada penelitian ini merupakan penyediaan informasi untuk sebuh keputusan program sebagai sebuah rekaman ataupun sebagai arsip sebuah prosedur yang telah terjadi. Indikator evaluasi proses dalam implementasi kurikulum 2013 ini terdiri dari: 1) Proses pembelajaran. 2) Proses penilaian

\section{Proses Pembelajaran}

Komponen atau indikator sebagai aspek keterlaksanaan sebuah proses pembelajaran dalam penelitian ini merupakan evaluasi 
proses meliputi koleksi data penilaian yang telah ditentukan dan diterapkan dalam prktek pembelajaran.

Tabel 5. Analisis hasil data Kuesioner Proses Pembelajaran

\begin{tabular}{ccccccc}
\hline No & $\begin{array}{c}\text { Respo } \\
\text { nden }\end{array}$ & $\begin{array}{c}\text { Jum } \\
\text { lah }\end{array}$ & n & N & DP & $\begin{array}{c}\text { Kesim } \\
\text { pulan }\end{array}$ \\
\hline 1 & Guru & 4 & 44 & 60 & 73,3 & Baik \\
& & & & & $3 \%$ & \\
\hline & Jumlah & 4 & & & & \\
\hline
\end{tabular}

Keterangan:

$\mathrm{n}=$ Skor nilai yang diperoleh dari jawaban responden

$\mathrm{N}=$ Skor ideal seluruh responden

DP $=$ Deskripsi persentase

Proses Penilaian

Tabel 6. Analisis hasil data Kuesioner Proses Penilaian

\begin{tabular}{ccccccc}
\hline $\begin{array}{c}\text { No Respon } \\
\text { den }\end{array}$ & Jumlah & n & N & DP & $\begin{array}{c}\text { Kesim- } \\
\text { pulan }\end{array}$ \\
\hline 1 & Guru & 4 & 30 & 60 & $\begin{array}{l}50 \\
\%\end{array}$ & $\begin{array}{l}\text { Kurang } \\
\text { Baik }\end{array}$ \\
\hline & Jumlah & 4 & & & & \\
\hline
\end{tabular}

Keterangan:

$\mathrm{n}=$ Skor nilai yang diperoleh dari jawaban responden

$\mathrm{N}=$ Skor ideal seluruh responden

DP $=$ Deskripsi persentase

Berdasarkan hasil perhitungan data kuesioner bahwa persentase pendapat guru tentang proses penilaian adalah $50 \%$, hal ini merupakan sebuah kategori yang kurang baik. a) Evaluasi Keluaran (produk) Dalam Implementasi Kurikulum 2013. Menurut Arikunto dan Jabar (2010:47) evaluasi keluaran/produk atau hasil, "merupakan tahap akhir dari serangkaian evaluasi program". Indikator evaluasi keluaran dalam implementasi kurikulum 2013 pada penelitian ini adalah "Tanggapan Umum Tentang implementasi Kurikulum 2013". "Tidak ada kurikulum yang tidak bagus, namun dengan kurikulum 2013 diharapkan dapat menghasilkan insan Indonesia yang produktif, kreatif, inovatif dan efektif melalui penguatan sikap, keterampilan dan pengetahuan yang terintegrasi. Masalah yang ada yaitu didalam tema pelajaran olahraga masih ada, sedangkan buku olahraga sudah tersendiri. Cara mengatasinya adalah guru dapat menyesuaikan sendiri teentang tema tersebut. fasilitas pendukung guru olahraga adalah guru mata pelajaran, sebaiknya pemerintah menentukan sikap dengan tegas dari kelas 1 sd 6 sebaiknya guru olahraga tetap diberdayakan. Pelaksanaan kurikulum 2013 belum berhasil kemungkinan disebabkan oleh kurikulum 2013 banyak hal yang baru, misalnya silabus, model Rencana Pelaksanaan Pembelajaran, pendekatan pembelajaran (5 M) dan sistem penilaian, dan tak kalah pentingnya adalah keterbatasan atau keterlambatan buku paket". 1) Kepala Sekolah SD Negeri 01 Mempawah Hilir. 2) Kepsek SD Negeri 02 Mempawah Hilir. 3) Kepsek SD Negeri 08 Mempawah Hilir. 4) Kepsek SD Negeri 22 mempawah Hilir. 5) Kepala Sekolah SD Negeri 01 Mempawah Hilir. 6) Kepala Sekolah SD Negeri 02 Mempawah Hilir. 7) Kepala Sekolah SD Negeri 08 Mempawah Hilir. 8) Kepala Sekolah SD Negeri 22 Mempawah Hilir. 9) Guru Penjaskes-Orkes SD Negeri 01 Mempawah Hilir. 10) Guru Penjaskes-Orkes SD Negeri 02 Mempawah Hilir. "Tidak begitu memahmi secara jelas. 11) Guru Penjaskes-Orkes SD Negeri 08 Mempawah Hilir. 12) Guru Penjaskes-Orkes SD Negeri 22 Mempawah Hilir. 13) Pengawas SD Negeri 4 Mempawah Hilir.

Strategi Untuk Mengatasi Permasalahan dalam Implementasi Kurikulum 2013 Pada Mata Pelajaran Penjaskes-Orkes di SD Negeri 4 Kecamatan Mempawah Hilir Kabupaten Mempawah. Strategi dalam upaya mengatasi permasalahan yang ditemukan dan dihadapi selama ini khususnya pada implementasi kurikulum 2013 mata pelajaran penjaskes-orkes di SD Negeri 4 kecamatan Mempawah Hilir Kabupaten Pontianak di dasarkan atas kendala yang dihadapi pada setiap sekolah yang ada diperoleh dari hasil wawancara dengan kepala sekolah dan guru sebagai berikut: "Kedepannya kami akan membuat perencanaan lebih fleksibel lagi berdasarkan analisis kebutuhan, khususnya yang terkait dengan mata pelajaran penjaskes-orkes, baik itu guru dan 
melakukan jalinan kerjasama atau sinergiritas dengan pihak dinas pendidikan yang berhubungan dengan kegiatan pelatihan, pendampingan dan lainnya". 1) Kepala Sekolah SD Negeri 01 Mempawah Hilir. 2) Kepala Sekolah SD Negeri 02 Mempawah Hilir. 3) Kepala Sekolah SD Negeri 08 Mempawah Hilir.

\section{Pembahasan}

Sarana dan prasarana secara keseluruhan menurut kepala sekolah, guru, siswa dan komite pada sekolah 4 kecamatan Mempawah Hilir tergolong baik, hanya pengawas saja yang mengemukakan cukup, artinya masih perlu pembenahan dan penambahan fasilitas untuk olahraga. Pemahaman guru terhadap kurikulum 2013 pada Sekolah Dasar Negeri 4 Kecamatan Mempawah Hilir Kabupaten Mempawah, diperoleh bahwa dari empat sekolah yang tergabung pada sekolah 4 tersebut, hanya satu sekolah yang belum banyak mengetahui tentang kurikulum 2013, sedangkan tiga sekolah sudah lebih banyak mengetahui dan sudah menerapkannya.

Data yang diperoleh menunjukkan bahwa orang tua siswa/komite Sekolah dalam pengembangan kurikulum pada Sekolah Dasar Negeri 4 Kecamatan Mempawah Hilir Kabupaten Mempawah belum pernah diberitahukan oleh pihak sekolah jika sekarang telah menggunakan kurikulum 2013, belum bisa memberikan pendapat karena belum mengetahuinya, sebaiknya pemerintah gencar untuk mensosialisasikan kurikulum 2013 ini baik langsung terhadap masyarakat ataupun lewat instansi terkait, seperti dinas pendidikan dan kebudayaan, pemda ataupun kepala sekolah.

Kami selaku orang tua siswa sering dilibatkan dan diundang dalam setiap kegiatan yang diadakan pihak sekolah, namun secara pribadi saya tidak pernah mengetahui kalau sekolah sudah mulai memberlakukan kurikulum 2013. Komite sekolah ataupun orang tua siswa hanya sebagian saja yang mengetahui kalau sekolah sudah melaksanakan kurikulum 2013, namun terdapat juga yang sama sekali komite ataupun orang tua siswa.
Oleh sebab itu hal-hal yang perlu dilakukan oleh pihak sekolah adalah jalinan komunikasi antara pihak sekolah dengan komite sekolah ataupun orang tua siswa untuk dapat memberikan berbagai informasi yang terkait dengan implementasi kurikulum 2013 ini, agar tidak terjadi kebingungan atau kesalahpahaman tentang implementasi kurikulum 2013.

Kendala yang dihadapi dalam implementasi Kurikulum 2013 mata pelajaran Penjaskes-Orkes di SDN 4 Mempawah Hilir. Kendala yang dihadapi dalam evaluasi masukan dalam implementasi kurikulum 2013 diantaranya adalah a) Buku Pedoman guru dan siswa, b) Pelatihan dan pendampingan guru, c) Manajemen Pembelajaran, dan d) Layanan kesiswaan. Buku pedoman untuk guru memuat materi pelajaran dan sistemmatika proses pembelajaran yang akan digunakan sebagai sebuah pedoman jika ingin mengajar di kelas. Untuk melaksanakan kurikulum 2013.

Hasil wawancara yang dilakukan terhadap kepala sekolah diperoleh bahwa buku pedoman untuk guru dan siswa tentang kurikulum 2013 ada dan pemesanan dilakukan secara online, buku pedoman tersebut dapat membantu dlam pelaksanaan kurikulum 2013, kendala yang ditemukan adalah masih rancu, karena adanya pemisahan untuk mapel olahraga mengajar di kelas atas, sementara gutu kelas bawah materi olahraga masuk dalam tema.

Terdapat juga perolehan buku pedoman tentang kurikulum 2013 untuk siswa dan guru yang pengadaannya dilakukan pembelian melalui penerbit dengan menggunakan dana bos, keberadaan buku pedoman tersebut sangat membantu, kendala yang dihadapi ada tetapi dapat diatasi, upaya yang dapat dilakukan dapat diupayakan melalui pertemuan KKG. Secara umum kegiatan sosialisasi dan persiapan implementasi kurikulum 2013 di Sekolah Dasar Negeri 4 Kecamatan Mempawah Hilir Kabupaten Mempawah telah dilakukan pelatihan bagi guru, kepala sekolah dan pengawas. Pelatihan dilakukan secara berjenjang sesuai dengan tingkatan sekolah 
masing-masing dan lokasi sekolah masingmasing. pelatihan ini diselenggarakan oleh Dinas Pendidikan melalui sekolah dan lembaga Penjamin Mutu Pendidikan. Kegiatan pelatihan dan pendampingan guru meliputi aspek pelatihan tentang a) Kesesuaian materi pelatihan dengan kebutuhan guru, b) Kesesuaian kompetensi instruktur yang memberikan pelatihan dengan materi pelatihan, c) Kesesuaian alokasi waktu yang tersedia dengan materi pelatihan, d) Penyampaian materi, dan e) Pengembangan Karakter. Aspek pendampingan meliputi kunjungan dan pendampingan yang dilakukan oleh TIM dari dinas pendidikan, hasil analisis data yang diperoleh dari kepala sekolah, guru dan pengawas sebagian besar sudah baik. Secara rinci pelaksanaan pelatihan terhadap kepala sekolah, guru dan pengawas, diperoleh bahwa; persepsi kepala sekolah "pelatihan berjalan dengan cukup baik, yaitu 66,67\% sedang persepsi guru juga sudah kurang baik, yaitu $50 \%$. dan persepsi pengawas 66,67 \% tergolong Cukup Baik. Manajemen pembelajaran penting untuk diperhatikan, karena manajemen pembelajaran merupakan proses awal dari setiap kegiatan yang dilakukan. Sebuah manajemen yang baik akan dapat menentukan baik buruknya suatu proses pembelajaran, kesemuanya ini telah dimulai ketika seorang guru mempersiapkan Rencana Proses Pembelajaran.

Rata-rata persentase adalah $75 \%$, artinya aspek manajemen pembelajaran di sekolah sudah melaksanakan kurikulum 2013 dengan baik, hasil evaluasi menunjukkan bahwa pihak sekolah sudah berusaha dengan baik untuk mengelola atau mengatur segala aktivitas pembelajaran agar sesuai dengan ketentuan yang ada di kurikulum 2013 walaupun masih terdapat kekurangan dibeberapa hal seperti buku pedoman pelaksanaan kurikulum 2013, baik untuk guru maupun untuk siswa serta ketersediaan fasilitas pendukung khususnya dalam pelajaran penjaskes-orkes.

Iayanan kesiswaan berdasarkan yang dilaksanakan oleh komite atau orang tua siswa dengan indikator yaitu: 1). Layanan bantuan kesulitan belajar, 2). Layanan konsultasi dengan orang tua dan siswa, 3). Layanan adminstrasi kesiswaan, 4). Layanan peminatan, dan 5). Layanan bimbingan dan konseling diperoleh sebanyak $72 \%$ layanan sudah baik dalam implementasi kurikulum 2013, sehingga dikatakan bahwa layanan kesiswaan di empat sekolah dasar negeri 4 Kecamatan Mempawah Hilir, Kabupaten Mempawah telah terlaksana dengan baik.

Harapan ke depan layanan kesiswaan dapat terus untuk ditingkatkan kualitasnya agar program layanan yang diprogramkan dapat terlaksanakan sebagaimana mestinya. Guru penjaskes-orkes di sekolah negeri 4 Kecamatan Mempawah Hilir, Kabupaten Mempawah memilih untuk menyediakan buku secara mandiri, artinya dalam hal ini dibeli sendiri di toko buku yang tersedia. Hal ini terjadi dikarenakan buku yang semestinya disediakan oleh pihak sekolah terjadi kendala dan beberapa hambatan karena pencairan dana bos dan manajemen yang berbelit untuk pengadaannya. Hal inilah yang menyebabkan guru dan murid memutuskan untuk membeli buku dengan cara sendiri di toko buku.

Indikator evaluasi proses dalam implementasi kurikulum 2013 ini terdiri dari a) Proses pembelajaran, dan Proses penilaian. Evaluasi proses menurut guru mata pelajaran penjaskes-orkes meliputi koleksi data penilaian yang telah ditentukan dan diterapkan dalam prktek pembelajaran. Data yang diperoleh menunjukkan bahwa proses pembelajaran yang dilaksanakan dengan pendekatan kurikulum 2013 pada sekolah 4 kecamatan Mempawah Hilir Kabupaten Mempawah sudah berjalan dengan baik. Pendapat guru tentang proses penilaian yang dilaksanakan terkait implementasi kurikulum 2013, khusus mata pelajaran penjaskes-orkes diperoleh skor $50 \%$, hal ini merupakan sebuah kategori yang kurang baik. Dalam evaluasi hasil atau output guna mengetahui capaian program implementasi Kurikulum 2013 mata pelajaran Penjaskes-orkes di SDN 4 Mempawah Hilir. Dikatakan oleh kepala sekolah bahwa tidak ada kurikulum yang tidak bagus, namun dengan kurikulum 2013 diharapkan dapat menghasilkan insan 
Indonesia yang produktif, kreatif, inovatif dan efektif melalui penguatan sikap, keterampilan dan pengetahuan yang terintegrasi.

Masalah yang ada yaitu didalam tema pelajaran olahraga masih ada, sedangkan buku olahraga sudah tersendiri. Cara mengatasinya adalah guru dapat menyesuaikan sendiri teentang tema tersebut. fasilitas pendukung guru olahraga adalah guru mata pelajaran, sebaiknya pemerintah menentukan sikap dengan tegas dari kelas 1 sd 6 sebaiknya guru olahraga tetap diberdayakan.

Pelaksanaan kurikulum 2013 belum berhasil kemungkinan disebabkan oleh kurikulum 2013 banyak hal yang baru, misalnya silabus, model Rencana Pelaksanaan Pembelajaran, pendekatan pembelajaran (5.M) dan sistem penilaian, dan tak kalah pentingnya adalah keterbatasan atau keterlambatan buku paket.

\section{SIMPULAN DAN SARAN Simpulan}

Berdasarkan dari hasil penelitian dan pembahasan, maka penulis dapat menarik beberapa kesimpulan dan mengemukakan beberapa saran sebagai berikut: 1) Dalam Penilaian implementasi Kurikulum 2013 mata pelajaran Penjas di SD NEGERI 4 Mempawah Hilir sebagaian besar sudah berjalan dengan lancar, dari 4 sekolah yang tergabung dalam sekolah 4 kecamatan Mempawah Hilir Kabupaten Mempawah hanya satu sekolah yang belum sepenuhnya merencanakan program implementasi kurikulum 2013, khusus mata pelajaran penjaskes, hal ini dikarenakan masih kurangnya sosialisasi dan pendampingan terhadap guru dan masih minimnya sarana dan prasarana yang tersedia di sekolah. 2) Kendala yang dihadapi dalam penilaian implementasi Kurikulum 2013 mata pelajaran Penjasdi SD Negeri 4 kecamatan Mempawah Hilir Kabupaten Mempawah yaitu keterbatasan guru mata pelajaran Penjas yang ada di sekolah dan keterbatasan sarana dan prasarana untuk menunjang kegiatan praktek mata pelajaran Penjas serta minimnya sarana penunjang lainnya seperti buku penunjang, perpustakaan dan jaringan internet guna menunjang kelancaran informasi yang terkait dengan kurikulum 2013. 3) Strategi untuk mengatasi kendala dalam penilaian implementasi Kurikulum 2013 mata pelajaran Penjas di SD NEGERI 4 Mempawah Hilir yang perlu dipersiapkan lebih lanjut adalah membuat perencanaan yang baik berdasarkan analisis kebutuhan dan adanya sinergi yang baik pula antara pemerintah pusat dengan pemerintah propinsi maupun dengan pemerintah daerah khususnya dinas pendidikan dan pihak sekolah. Capaian program implementasi Kurikulum 2013 mata pelajaran Penjasbagus, karena di dalam kegiatan proses belajar mengajar siswa yang lebih berperan aktif, sedangkan guru sebagai motivator. Hanya dalam proses penilaian yang masih banyak kebingungan, ini dikarenakan banyaknya komponen penilaian yang harus dilakukan sebagai tuntutan kurikulum 2013.

\section{Saran}

Berdasarkan hasil penelitian yang telah dilakukan, maka saran yang diberikan adalah: Sejalan dengan kesimpulan poin 1 tersebut, pihak dinas pendidikan dipandang perlu untuk lebih mengintensifkan implementasi kurikulum 2013 ini agar pelaksanaannya bisa berjalan bersama dengan sesama sekolah yang tergabung dalam Sekolah Dasar Negeri 4, khususnya di kecamatan Mempawah Hilir Kabupaten Mempawah. 1) Sejalan dengan penilaian input atau masukan dalam implementasi kurikulum 2013 pada Sekolah dasar Negeri 4 kecamatan Mempawah Hilir Kabupaten Mempawah, maka pihak dinas pendidikan dapat untuk selalu mensosialisasikan melalui kepala sekolah dan guru bidang studi, khususnya suru mata pelajaran penjas, agar ke depannya semua guru dapat memahami dengan jelas, sehingga pelaksanaannya dapat berjalan secara maksimal. 2) Pihak dinas pendidikan atau pihak Lembaga Penjamin Mutu Pendidikan sebaiknya dapat terus melakukan sosialiasi ataupun pelatihan terhadap guru mata pelajaran Penjas terkait dengan prose proses 
penilaian yang dilakukan. 3) Pihak terkait dalam hal ini dinas pendidikan dan pihak sekolah perlu Fasilitas pendukung guru olahraga adalah guru mata pelajaran, sebaiknya pemerintah menentukan sikap dengan tegas dari kelas 1 sd 6 sebaiknya guru olahraga tetap diberdayakan. fasilitas pendukung yang diperlukan guru olahraga adalah fasilitas lapangan dan peralatan olahraga yang lengkap dan sesuai, dan sebaiknya pula pemerintah menentukan sikap dengan tegas dari kelas 1 sd 6 sebaiknya guru olahraga tetap diberdayakan.

\section{DAFTAR RUJUKAN}

Arikunto, S. (2006). Prosedur Penelitian: Suatu Pendekatan Praktik. Jakarta: Rineka Cipta.

Arikunto, S. (2007). Manajemen Penelitian. Jakarta: PT Rineka Cipta

Edison. (2009). Penelitian dan Penilaian Dalam Bidang Pendidikan:Penilaian CIPP,(Online), (http://ed150n5.blogspo t.com/2009/04/penilaian-ci pp.html, 11 April 2011)

Fuddin, V. B.(2007). Penilaian Program, (, J. Online), (http:// fuddin. wordpress. com .2007/07/17/ penilaian-program/, diakses 11 April 2011)

Inggit, K. (2009). Pengertian dan Konsep Penilaian, Penilaian dan

Pengukuran (Online), (http:// santriw4n. wordpress. com/2009/ 11/ 18/pengertian dan-konsep-penilaian-penilaian-danpengukuran/, diakses 11 April 2011)

Ali, M. (2010), Guru Dalam Proses Belajar Mengajar, Bandung: Sinar Baru Algensindo.

Aunurrahman, (2009), Belajar dan Pembelajaran, Bandung : Alfabeta

Basleman, A \& Syamsu, M. (2011), Teori Belajar Orang Dewasa, Bandung : PT. Remaja Rosdakarya.

Grafura, L \& Ari, W. (2012). Metode dan Strategi Pembelajaran Yang Unik, Yogyakarta : AR-RUZZ MEDIA
Hamalik, O. (2011), Proses Belajar, jakarta : Bumi Aksara

Khanifatul, (2013), Pembelajaran Inovatif, Yogyakarta : AR-Ruzz Media

Made, I. W.(2006). Metodologi Penelitian Sosial Ekonomi, Yogyakarta: Penerbit Andi

Mulyono, (2009), Penelitian Penilaian Kebijakan, (online),(http;//mulyono,

staff,uns.ac.id/2009/05/13/penelitianpenilaian-kebijaka/, diakses 12 pebruari 2018.

Nawawi., Hadari, (2012), Metode Penelitian Bidang Sosial, Yogyakarta: Gajahmada university Press.

Rika Dwi,Kurniasih, (2009), Teknik Penilaian Perencanaan, (online). http://images.rikania09multiply.multiply content.com//attachment/0/SUdfiwoKC F8AAuyo81/Rika\%20Eva.doc?nmid=14 8657139,diakses 18 Pebruari2018

Sugiyono., (2012), Metode Penelitian Administrasi, Dilengkapi Dengan Metode $R \& D$, Bandung : Alfabeta

Susan Thomas dan Roger Kaufman, (1980), Evaluation Withhout Fear, London: New Viewpoints

Mbulu, (1995), Penilaian Program Konsep dasar, Pendekatan Model dan

Prosedur Pelaksanaan, Malang: Departemen Pendidikan dan Kebudayaan,IKIP Malang.

Tayipnapis, FY. (1989). Penilaian Program, Jakarta: Departemen Pendidikan dan

Kebudayaan, Dirjen Dikti, Proyek Pengembangan lembaga Pendidikan Tenaga kependidikan.

Zulyarman, (2007),Penilaian Kurikulum: Pengertian, Kepentingan dan Masalah YangDihadapi,(online).(http://zulharma n79. wordpress.com/2007/08/04/penilaia n-kurikulum-kepentingan-dan-masalahyang dihadapi/,diakses 5 januari 2018. 